\title{
The relationship between consumption of animal products and expenditure levels with Quality of Life Scores (SF-36) by veterinary students in Turkey
}

\author{
[A relação entre o consumo de produtos de origem animal e níveis de gasto com Scores de \\ Qualidade de Vida (SF-36) por alunos de veterinária na Turquia] \\ M.A. Tekindal ${ }^{1}$, M.B. Çevriml ${ }^{2}$, A.C. Akin $^{3}$, B. Mat $^{2}$, M.S. Arikan ${ }^{4}$, M. Polat ${ }^{*}$ \\ ${ }^{1}$ Faculty of Medicine - İzmir Katip Çelebi University - İzmir, Turkey \\ ${ }^{2}$ Faculty of Veterinary Medicine - Selçuk University - Konya, Turkey \\ ${ }^{3}$ Faculty of Veterinary Medicine - Mehmet Akif Ersoy University - Burdur, Turkey \\ ${ }^{4}$ Faculty of Veterinary Medicine - Frrat University - Elazig, Turkey \\ ${ }^{5}$ Faculty of Veterinary Medicine - Kastamonu University - Kastamonu, Turkey
}

\begin{abstract}
The present study aimed to calculate the quality of life scores (Short Form-36) of veterinary students in Turkey and review their scores with regards to different socio-demographic characteristics. A total of 1211 students studying veterinary medicine in 26 different faculties in Turkey were selected by stratified sampling method and were asked questions concerning their consumption of and expenditures on foods of animal origin using the SF-36 questionnaire between October and December 2018. Significant differences were found between SF-36 components in terms of year level, gender, accommodation status, income level, and level of expenditures on foods and foods of animal origin $(\mathrm{P}<0.01)$. With the increase in the size of the budget set aside for animal products, the scores in the domains of physical functioning, vitality, mental health, pain, and general health perception also enhanced, and statistically significant differences were found $(\mathrm{P}<0.01)$. The low quality of life scores of the veterinary students can be improved by increasing their income level and consumption of foods of animal origin. This will ensure that they are energetic and have the desired level of mental and general health perceptions.
\end{abstract}

Keywords: expenditure, foods of animal origin, income, quality of life, student, veterinary medicine

\section{RESUMO}

O presente estudo teve como objetivo calcular os escores de qualidade de vida (SF-36) de estudantes de veterinária na Turquia e revisar seus escores no que diz respeito a diferentes características sociodemográficas. Um total de 1211 estudantes de medicina veterinária em 26 faculdades diferentes na Turquia foram selecionados pelo método de amostragem estratificada e foram questionadas sobre o consumo e as despesas com alimentos de origem animal usando o questionário SF-36 entre outubro e dezembro de 2018. Diferenças significativas foram encontradas entre os participantes do SF-36 em termos de nível do ano, gênero, status de acomodação, nível de renda e nível de gastos com alimentos $e$ alimentos de origem animal $(P<0,01)$. Com o aumento do orçamento reservado para produtos de origem animal, as pontuações nos domínios de funcionamento físico, vitalidade, saúde mental, dor e percepção geral de saúde também aumentaram e foram encontradas diferenças estatisticamente significativas $(P$ $<0,01)$. Os baixos índices de qualidade de vida dos veterinários podem ser melhorados, aumentando o nível de renda e o consumo de alimentos de origem animal. Isso garantirá mais energia e que tenham o nível desejado de percepção mental e geral de saúde.

Palavras-chave: gastos, alimentos de origem animal, renda, qualidade de vida, estudante, medicina veterinária

Recebido em 15 de maio de 2020

Aceito em 4 de junho de 2020

*Auto para correspondência (corresponding author)

E-mail: muratpolat@kastamonu.edu.tr 


\section{INTRODUCTION}

According to the World Health Organization, quality of life is the perception of individuals toward their position in life with regards to the culture and value systems in which they dwell. Their goals, expectations, standards, and concerns are mingled with their quality of life. It is thus defined as their perception of their position in life in the context of the culture and value systems in which they reside and is related to their goals, expectations, standards, and concerns (The World..., 1995).

The factors influencing the quality of life score are referred to as quality of life indicators (Boylu and Paçacioğlu, 2016). Nutrition and socioeconomic level are considered as major indicators. Per capita consumption of meat and animal protein contributes to one of the primary nutrition-related criteria used to estimate the status of development of the countries (Yücel, 2016). The per capita consumption of red meat in Turkey is $14.6 \mathrm{~kg}$. This value is much lower than the average values in European countries and the US (Meat..., 2018).

Reduction of the disease prevalence and enhancement of the quality of life can be achieved by improving the quality and quantity of nutrition. The socioeconomic status is a determining factor for the variation in diet and level of nutrition (McNaughton et al., 2012). The type of university attended by the student, the faculty, age, gender, accommodation status, income level, and social environment of the student are the socioeconomic variables that encompass the socioeconomic level of the students (Pekmezovic et al., 2011). Quality of life in educational niches has been a burning topic of research in the recent world, addressed in various academic studies (Pekmezovic et al., 2011; Goldin et al., 2007). In Turkey, the fiveyear veterinary education in universities is associated with several exhausting stress factors, as observed in other countries (Labbafinejad $e t$ al., 2016; Kogan et al., 2005; Gelberg and Gelberg, 2005).

During this intense education program, veterinary students receive vocational education as well as training pertaining to the process of production of foods of animal origin from the farm to the table, learn the significance of consumption of such foods for society and the functions assumed by the livestock sector. The quality of life of these students may be adversely affected by this intensive and challenging education process (Labbafinejad et al., 2016). A limited number of studies at the local level have been conducted to estimate the quality of life of university students in Turkey (Arslan et al., 2009; Tozun et al., 2010; Unsal et al., 2010; Argon and Kösterelioğlu, 2009).The students studying in health education programs generally exhibit a better quality of life scores than the students in other faculties. It is reported that there is a need to unearth the factors underlying it and that studies should be conducted concerning this issue (Pekmezovic et al., 2011).

The main objective of the present study was to calculate the quality of life scores using short form-36 (SF-36) among the students of veterinary medicine in Turkey. The scores were further used to review their quality of life in terms of year level, accommodation status, and gender as well as their individual monthly income level, monthly expenditures on foods, monthly expenditures on foods of animal origin and quality of life, and to determine the relationship between the domains of quality of life. The present study will contribute to the relevant literature regarding the quality of life of veterinary students.

The primary motivation behind the study was to investigate the effects of cultural differences in protein-based nutrition of veterinary faculty students. For this reason, their quality of life was measured with the SF-36 quality of life scale. Measured quality of life, obtained from the students of all veterinary faculties in Turkey, was evaluated within the scope of differences and relationships with protein-based foods in Turkey. This cross-sectional study was conducted in Turkey and applied to determine a specific situation.

\section{MATERIAL AND METHODS}

The questions concerning the monthly income level, monthly expenditures on foods and foods of animal origin, and amount of consumption, other than those in SF-36, were designed consulting relevant previous studies (Cevger et al., 2008; Sarı̈̈kan et al., 2007; Erdoğan and Çiçek, 2015; Şentürk, 2011). Computing the 
stratified sampling method with a confidence interval of $95 \%$, we calculated that at least 623 students in total, among the 10,946 students of veterinary medicine in 26 different faculties that deliver formal education in Turkey, should be employed. According to the total stratum ratios, we reached 1,211 students across Turkey. The details are given in equation 1 (Botev and Ridder, 2017; Esfahani and Dougherty, 2014).

$n_{0}=\frac{N t^{2} p q}{d^{2}(N-1)+t^{2} p q}=\frac{10946(2.57)^{2} 0.5 * 0.5}{0.05^{2}(10946-1)+(2.57)^{2} * 0.5 * 0.5} \cong 623$ [1]

where $\mathrm{t}$-able value for a $99 \%$ confidence interval is 2.57; since there are male and female students, $\mathrm{p}=0.5$ and $\mathrm{q}=0.5 ; \mathrm{N}=$ number of individuals in the population; $p=$ frequency of occurrence of the incident under consideration; $q=$ frequency of non-occurrence of the incident under consideration; $\mathrm{t}=$ theoretical value in the $\mathrm{t}$-table at the specified degree of freedom and the identified level of significance; $d=$ deviation according to the frequency of occurrence of the incident.

Participation in the study was pursued completely on a voluntary basis, and the identity of the participants was not enquired. The approval of the research ethics committee for the study was obtained from Mehmet Akif Ersoy University's Ethics Committee (GO 2018/16), and the questionnaires were provided to all participants of the study between October 2018 and November 2018. SPSS 25 was employed to assess the data (IBM..., 2017. IBM SPSS Statistics for Windows, Version 25.0. Armonk, NY: IBM Corp.). The mean \pm standard deviation, percentage, and frequency values of the variables were used. The variables were tested (Shapiro Wilk and Levene Test) after verifying their normality and homoscedasticity.

To examine the significance of differences between the two groups during the data analysis, "Student's t-Test" was used where the prerequisites to the parametric test were met, and the "Mann-Whitney U-test" was used where they were not. A comparison of three or more groups was computed by One-Way Analysis of Variance (ANOVA) followed by post-hoc Tukey HSD, a multiple comparison test. Where the prerequisites to the parametric test were not met, the Kruskal Wallis test and Bonferroni-Dunn test, a multiple comparison test, were conducted.
When the criteria for the parametric test were fulfilled, the relationship between the two continuous variables was assessed using Pearson's Correlation Coefficient, and Spearman's Correlation Coefficient was used, where they were not. The significance level of the tests was assumed to be $\mathrm{P}<0.05$ and $\mathrm{P}<0.01$.

Firstly, the assessment was made by an approach that provided a total of 8 scores individually for each of the eight health domains in SF-36. The scores for each domain were calculated by the summation of all the scores for the answers given by the participants. The scores for the health domains in SF-36 were evaluated at four stages. In the first stage, the values of the answered questions were recorded. The recording was done merely for items $1,6,7,8,9 \mathrm{a}-9 \mathrm{~d}, 9 \mathrm{e}, 9 \mathrm{~h}$, $10 \mathrm{~b}$, and 10d. A better health condition is represented by a high score, whereas lower scores represent an unfavorable health status (Jenkinson et al., 1997; Walters and Brazier, 2003; Brazier et al., 2002; Franks et al., 2004).

The scores for the unanswered questions were determined in the second phase. At least half of the questions in each domain need to have been answered to obtain the score for the unanswered questions. The scores for the unanswered questions were then calculated from the average of the answered question. In the third stage, the raw scale score was computed by summing up the values of the questions making up each domain. In the fourth stage, the raw scale scores were assessed between 0 and 100. The following formula was used to convert the raw scale score:

Converted score: Raw scale score - minimum possible / possible score $\times 100$

e.g., If the physical functioning score is 21 , this score is converted as follows:

$[(21-10) / 20] * 100=55 \%$ (Ware and Sherbourne, 1992; Patric and Erichson, 1993; Koçyiğit et al., 1999).

\section{RESULTS}

Along with the SF-36 quality of life score evaluated in the present study, the perception of the participants regarding their frequency of eating out, the amount of consumption of animal products, and the level of consumption of animal products were also explored, and the findings were represented in Table 1. 
Table 1. Views of the participants regarding their frequency of eating out, the intervals at which they consume animal products and the level of consumption of the animal product

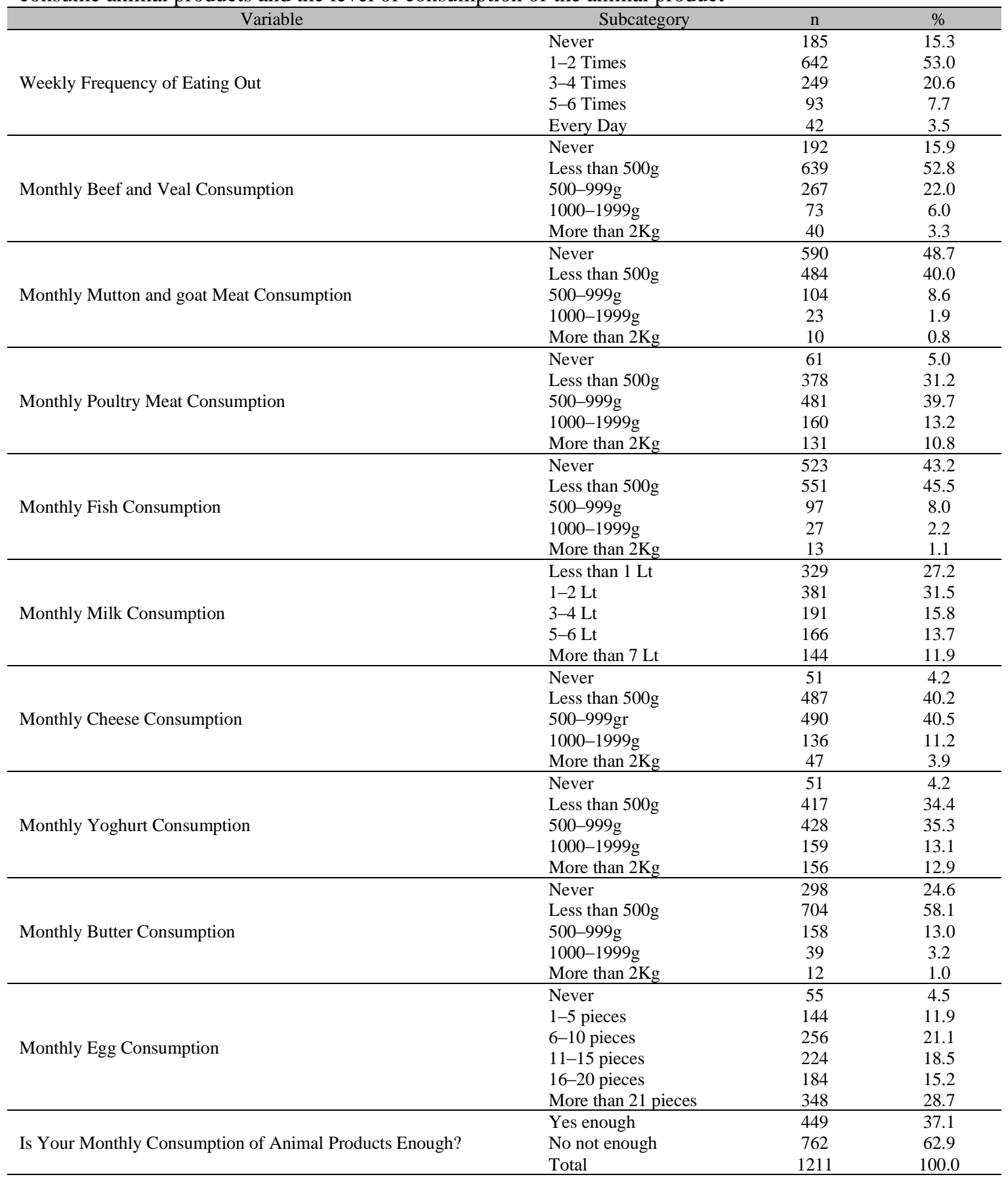

The weekly frequency of eating out observed $15.3 \%$ never ate out, $53 \%$ ate $1-2$ times a week, $20.6 \%$ ate $3-4$ times a week, $7.7 \%$ ate $5-6$ times a week, and $3.5 \%$ ate every day. Regarding the amount of consumption of animal products, $15.9 \%$ never consumed beef and veal, less than
$500 \mathrm{~g}$ of beef and veal were consumed by $52.8 \%$, and $22 \%$ consumed $500-999 \mathrm{~g}$ of beef and veal. Among the study population, $48.7 \%$ never consumed mutton and goat meat, $40 \%$ consumed less than $500 \mathrm{~g}$, whereas $8.6 \%$ consumed $500-$ 999 g. $5 \%$ never consumed poultry meat, $31.2 \%$ 
consumed less than 500g; on the other hand, $39.7 \%$ consumed $500-999 \mathrm{~g}$.

The participants who never had fish comprised of $43.2 \%$, whereas $45.5 \%$ consumed less than $500 \mathrm{~g}$. Less than 11 of milk was consumed by $27.2 \%$ of the study subjects, $31.5 \%$ consumed $1-$ 21 , and $15.8 \%$ consumed 3-4 1. Regarding cheese consumption, $4.2 \%$ never consumed cheese, $40.2 \%$ consumed less than $500 \mathrm{~g}$, and $40.5 \%$ consumed 500-999g. As to monthly yogurt consumption, $4.2 \%$ never consumed yogurt, 34.4\% consumed less than 500g, and $35.3 \%$ consumed $500-999 \mathrm{~g}$. $24.6 \%$ never had butter, $58.1 \%$ had less than $500 \mathrm{~g}$ of butter, and $13 \%$ had 500-999g of butter. Regarding monthly consumption of eggs, $4.5 \%$ never consumed, $11.9 \%$ consumed $1-5$ eggs, $21.1 \%$ 6-10 eggs, $18.5 \% \quad 11-15$ eggs, $15.2 \% \quad 16-20$ eggs, and $28.7 \%$ had more than 21 eggs. Considering these consumption levels, $62.9 \%$ of the veterinary students opined their monthly consumption of animal products was insufficient.

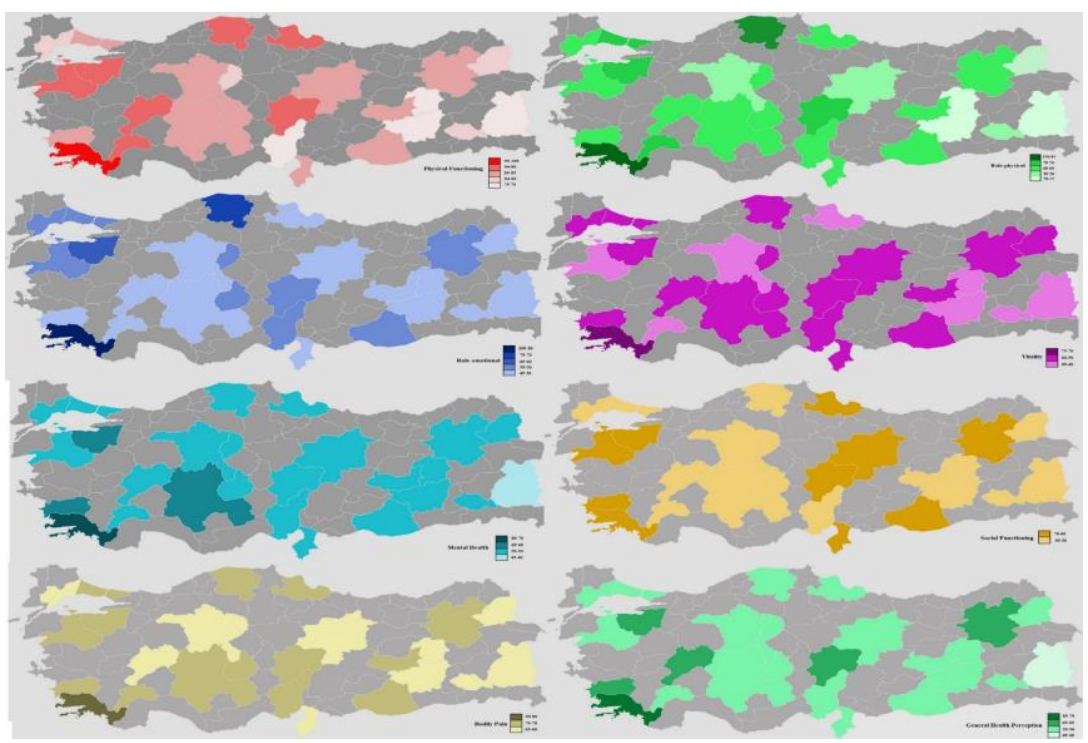

Figure 1 illustrated the distribution of the scores for each domain of the SF-36 in different colors by provinces: Physical Functioning in red, Physical Role Limitations in dark green, Emotional Role Limitations in dark blue, Vitality in purple, Mental Health in light blue, Social Functioning in orange, Bodily Pain in yellow, and general Health Perceptions in light green. Each province had only one faculty of veterinary medicine. The faculty/province with the highest score was highlighted in darker colors.

The scores of the veterinary students for each domain of the SF-36 were as follows: 86 in Physical Functioning, 63 in Physical Role Limitations, 50 in Emotional Role Limitations, 51 in Energy/Pep/Vitality, 55 in Mental Health, 59 in Social Role Functioning, 70 in Bodily Pain, and 57 in general Health Perceptions. Statistically significant differences were witnessed between the average scores of the SF36 domains by year level. While the average score for physical functioning among the firstyear students was 90.96 , it dropped to 84.87 among the fifth-year students. The difference between the average scores of these year levels was significant, as per the statistical analysis.
A similar observation was reported in case of physical role limitations. The average score for physical role limitations among the first-year students was 72; however, it reduced to 59 among the third-year and fifth-year students, the difference between them was statistically significant.

While the average scores for emotional role limitations were 60.07, 46.98, and 47.69 among the first-year students, the second-year students, and the third-year students, respectively. Statistical analysis showed this difference in score between them was statistically significant. A statistically significant difference was also recorded between the scores for the domain of vitality among the students of the second and 
fifth years. While the average score for the domain of mental health was 59 among the firstyear students, it diminished to 53 among the second- and third-year students. The difference between the average scores of the first-year and second- and third-year students were statistically significant. However, no significant difference was established between the scores of students in different years of their education with regards to the domains of social role functioning, bodily pain, and general health perceptions. Veterinary faculty students; SF-36 quality of life scale scores according to grade level, gender and accommodation status are given in Table 2 .

When the scores of the students for the domains of the SF-36 were calculated based on their gender, the average scores for physical functioning, energy/pep/vitality, bodily pain, and general health perceptions were higher among the male candidates, and the difference was statistically significant. However, no significant difference was found between the scores of male and female students in physical role limitations, emotional role limitations, mental health, and social functioning. Only in the case of physical role limitations, a statistically significant difference was obtained between the scores of students with different accommodation status. The difference in accommodation status developed from the students residing with their parents and the students living with their friends. In the other domains of the scale, an insignificant difference was noted between the average scores of students with different accommodation status.

The individual monthly income groups of veterinary students in several domains of the SF36 quality of life scale also demonstrated statistically significant differences. In the domain of physical role limitations, the average scores of the income groups of below 300 TRY (Turkish Lira), 300-499 TRY, and 750-999 TRY and the income groups of 500-749 TRY, 1000-1499 TRY, and above 1500 TRY were significantly different from each other. In the domain of emotional role limitations, a significant difference was observed between the average scores of the different income groups.

The income group above 1500 TRY was significantly different from the other income groups. In the domain of mental health, the average score of the income group above 1500
TRY was significantly higher as compared to all other groups, according to statistical analysis. In the domain of bodily pain, the difference between the scores of the income group 300-499 TRY and the income group above 1500 TRY was found to be statistically significant. In the domain of general health perceptions, significantly (based on statistical evidence) higher average score of the income group above 1500 TRY was perceived than that of the income groups 300-499 TRY and below 300 TRY. However, in the domains of physical functioning, energy/pep/vitality, and social functioning, no statistically significant difference was found between the average scores of the students in different income groups.

The average scores of the students in different groups of monthly expenditure on foods portrayed statistically significant difference, only in the domain of energy/pep/vitality. A statistically significant difference was observed between the average scores of the income groups below 150 TRY and 500 TRY and above in the domain of energy/pep/vitality. The scores of students in different groups of monthly individual expenditure on foods in the domains of physical role limitations, emotional role limitations, mental health, and social functioning failed to show any significant difference.

The average scores of the students in different groups of monthly individual expenditure on animal products were significantly different in various domains of the quality of life scale. The present study recorded a statistically significant difference between the group of students spending 50 TRY or below, and the group of students spending 100-149 TRY in the domain of physical functioning. A statistically significant difference was also evident between the group of students spending 50 TRY or below, and the group of students spending 200-299 TRY in the domain of energy/pep/vitality. The group of students spending 50 TRY or below, and the group of students spending 150-199 TRY and 200-299 TRY in the domain of mental health also showed a statistically significant difference. Difference between the group of students spending 50 TRY or below and 50-99 TRY and the group of students spending 200-299 TRY in the domain of bodily pain was also significant statistically. 
The relationship between...

Table 2. SF-36 quality of life scores by year level, gender, and accommodation status $* \mathrm{P}<0.05 * * \mathrm{P}<0.01$

\begin{tabular}{|c|c|c|c|c|c|c|c|c|c|c|c|}
\hline & & & & $\begin{array}{l}\text { Physical } \\
\text { Functioning }\end{array}$ & $\begin{array}{l}\text { Physical } \\
\text { Role } \\
\text { Limitations }\end{array}$ & $\begin{array}{l}\text { Emotional } \\
\text { Role } \\
\text { Limitations }\end{array}$ & Vitality & $\begin{array}{l}\text { Mental } \\
\text { Health }\end{array}$ & $\begin{array}{c}\text { Social } \\
\text { Functioning }\end{array}$ & $\begin{array}{l}\text { Bodily } \\
\text { Pain }\end{array}$ & $\begin{array}{c}\text { General } \\
\text { Health } \\
\text { Perceptions }\end{array}$ \\
\hline \multirow{3}{*}{ SF- 36} & & $\mathrm{n}$ & $\%$ & $\bar{x}_{ \pm S . D}$ & $\bar{x}_{ \pm S . D}$ & $\overline{\boldsymbol{x}}_{ \pm \mathrm{S} . \mathrm{D}}$ & $\bar{x}_{ \pm \text {S.D }}$ & $\overline{\boldsymbol{x}}_{ \pm \mathrm{S} . \mathrm{D}}$ & $\overline{\boldsymbol{x}}_{ \pm \text {S.D }}$ & $\overline{\overline{\boldsymbol{x}}} \pm$ S.D & $\bar{x} \pm$ S.D \\
\hline & Sub-Factor & & & $86.90 \pm$ & $63.71 \pm$ & $50.51 \pm$ & $51.29 \pm$ & $55.54 \pm$ & $59.28 \pm$ & $70.36 \pm$ & $57.00 \pm$ \\
\hline & Scores & & & 18.35 & 39.36 & 42.60 & 20.60 & 18.57 & 23.39 & 22.09 & 19.45 \\
\hline \multirow[t]{7}{*}{ Year student } & 1st year & 187 & 15.4 & $90.96 \pm$ & $72.33 \pm$ & $60.07 \pm$ & $53.37 \pm$ & $59.49 \pm$ & $60.14 \pm$ & $72.91 \pm$ & $60.16 \pm$ \\
\hline & 2nd year & 215 & 17.8 & $88.21 \pm$ & $67.21 \pm$ & $46.98 \pm$ & $47.70 \pm$ & $53.34 \pm$ & $59.52 \pm$ & $70.80 \pm$ & $56.60 \pm$ \\
\hline & & & & $15.70^{\mathrm{ab}}$ & $37.37^{\mathrm{ab}}$ & $42.51^{\mathrm{b}}$ & $21.00^{\mathrm{a}}$ & $18.00^{\mathrm{b}}$ & 22.59 & 22.32 & 18.95 \\
\hline & 3rd year & 195 & 16.1 & $85.87 \pm$ & $59.74 \pm$ & $47.69 \pm$ & $49.74 \pm$ & $53.31 \pm$ & $57.54 \pm$ & $70.68 \pm$ & $55.79 \pm$ \\
\hline & & & & $19.56^{\mathrm{ab}}$ & $40.07^{\mathrm{b}}$ & $41.85^{\mathrm{b}}$ & $20.82^{\mathrm{ab}}$ & $19.84^{\mathrm{b}}$ & 23.76 & 21.91 & 20.55 \\
\hline & 4 th year & 268 & 22.1 & $86.38 \pm$ & $62.87 \pm$ & $49.00 \pm$ & $50.62 \pm$ & $54.90 \pm$ & $59.04 \pm$ & $68.38 \pm$ & $56.92 \pm$ \\
\hline & $\mathrm{p}$ & & & $0.001 * *$ & $0.003 * *$ & $0.020 *$ & $0.001 * *$ & $0.001 * *$ & 0.810 & 0.303 & 0.180 \\
\hline \multirow[t]{6}{*}{ Gender } & Male & 705 & 58.2 & $87.90 \pm$ & $61.99 \pm$ & $52.39 \pm$ & $52.62 \pm$ & $55.52 \pm$ & $59.41 \pm$ & $73.60 \pm$ & $58.58 \pm$ \\
\hline & & & & 18.10 & 39.73 & 42.47 & 20.33 & 18.51 & 22.92 & 21.38 & 18.51 \\
\hline & Female & 506 & 41.8 & $85.50 \pm$ & $66.11 \pm$ & $47.89 \pm$ & $49.43 \pm$ & $55.58 \pm$ & $59.11 \pm$ & $65.84 \pm$ & $54.79 \pm$ \\
\hline & & & & 18.63 & 38.76 & 42.69 & 20.85 & 18.68 & 24.04 & 22.29 & 20.51 \\
\hline & $\begin{array}{l}\text { Test } \\
\text { Statistics }\end{array}$ & & & $2.235^{+}$ & $-1.798^{\dagger}$ & $1.813+$ & $2.66^{+}$ & $-0.058^{+}$ & $0.220 \dagger$ & $6.070^{\dagger}$ & $3.357^{+}$ \\
\hline & $\mathrm{p}$ & & & $0.020^{*}$ & 0.070 & 0.070 & $0.010^{*}$ & 0.950 & 0.830 & $0.001^{\text {*** }}$ & $0.001 * *$ \\
\hline \multirow{8}{*}{$\begin{array}{l}\text { Accommodation } \\
\text { status }\end{array}$} & With family & 220 & 18.2 & $89.61 \pm$ & $69.32 \pm$ & $56.36 \pm$ & $49.68 \pm$ & $55.36 \pm$ & $59.64 \pm$ & $71.45 \pm$ & $58.36 \pm$ \\
\hline & hostel & & & 18.12 & $36.16^{\mathrm{ab}}$ & 42.62 & 20.52 & 18.60 & 24.20 & 21.62 & 19.64 \\
\hline & Student & 528 & 43.6 & $86.40 \pm$ & $59.09 \pm$ & $46.97 \pm$ & $52.75 \pm$ & $56.62 \pm$ & $58.62 \pm$ & $71.24 \pm$ & $56.95 \pm$ \\
\hline & home & & & 18.23 & $40.92^{\mathrm{b}}$ & 43.60 & 20.00 & 18.39 & 23.69 & 22.62 & 19.67 \\
\hline & Other & 26 & 2.1 & $86.35 \pm$ & $67.31 \pm$ & $55.13 \pm$ & $49.04 \pm$ & $53.69 \pm$ & $55.98 \pm$ & $63.46 \pm$ & $56.15 \pm$ \\
\hline & & & & 23.69 & $38.58^{\mathrm{ab}}$ & 45.16 & 21.91 & 20.31 & 27.44 & 22.46 & 21.27 \\
\hline & $\begin{array}{l}\text { Test } \\
\text { Statistics }\end{array}$ & & & $1.465^{\ddagger}$ & $3.086^{\Psi}$ & $1.897^{\Psi}$ & $1.209^{\ddagger}$ & $1.038^{\ddagger}$ & $0.489^{\ddagger}$ & $1.245^{\ddagger}$ & $0.353^{\ddagger}$ \\
\hline & $\mathrm{p}$ & & & 0.199 & $0.009 *$ & 0.092 & 0.302 & 0.394 & 0.785 & 0.286 & 0.881 \\
\hline
\end{tabular}

There is no difference between the groups containing the same letter.

† Mann Whitney $U$ Test

+ Independent Sample $t$-Test

One-Way Analysis of Variance

${ }^{\Psi}$ Kruskal Wallis

The domain of general health perceptions also perceived a statistically significant difference between the group of students spending 50 TRY or below, and the group of students spending 150-199 TRY. It was estimated that the monthly average individual income of veterinary students in Turkey was 919.55 TRY, their monthly average expenditure on food was 293.07 TRY, and their monthly average expenditure on animal products was 111.07 TRY.

Veterinary faculty students; SF-36 quality of life scale scores according to individual monthly income, food expenditure and animal food expenditure intervals are given in Table 3. 
Tekindal et al.

Table 3. SF-36 quality of life scale scores by individual monthly income, expenditure on foods and expenditure on animal products

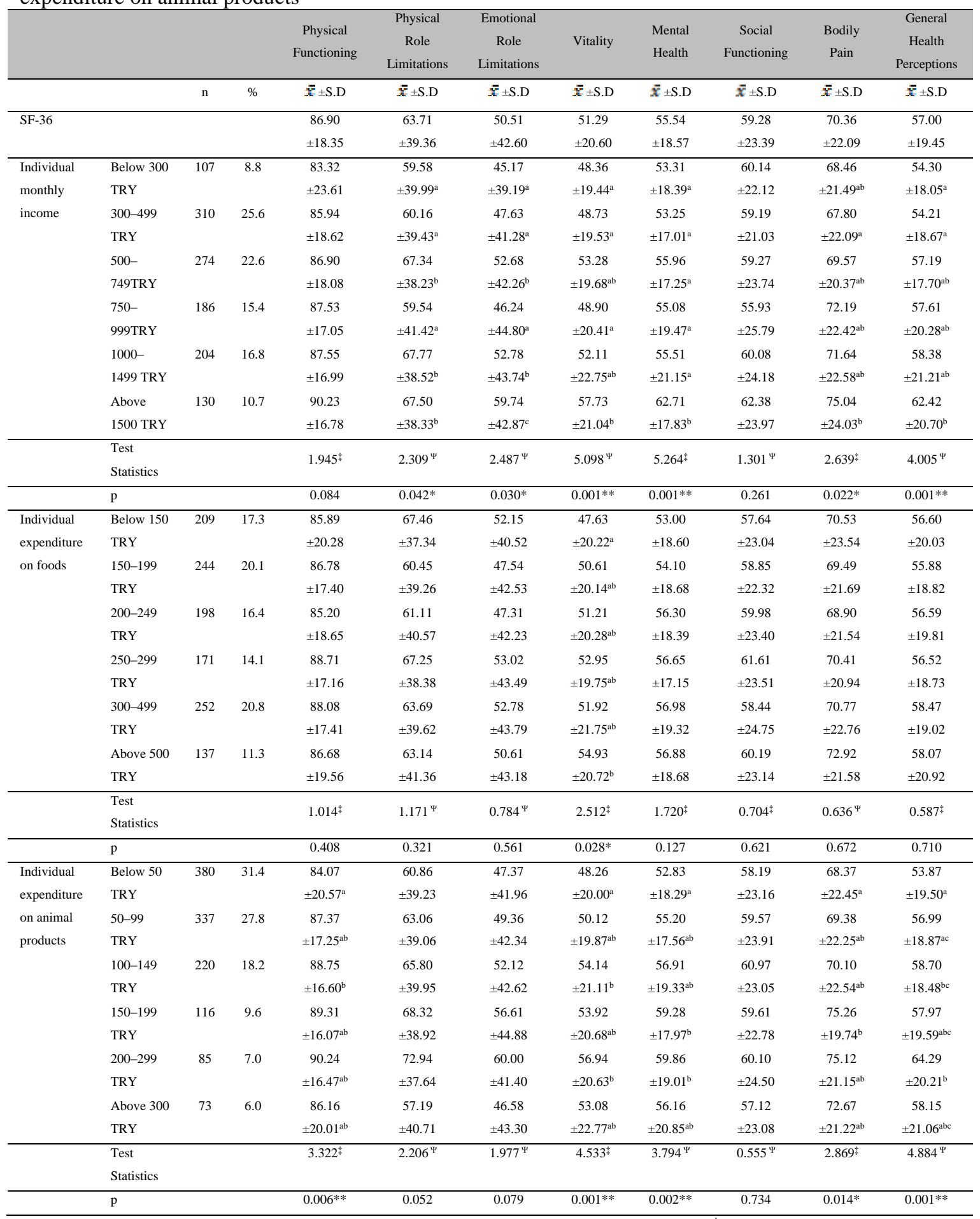

$* \mathrm{P}<0.05 * * \mathrm{P}<0.01 \quad$ There is no difference between the groups containing the same letter. ${ }^{\ddagger}$ One-Way Analysis of Variance.

${ }^{\Psi}$ Kruskal Wallis 
Table 4 illuminated significant positive relationship between monthly consumption of mutton and goat meat and emotional role limitations at a rate of $8.1 \%$, a significant positive correlation between monthly consumption of mutton and goat meat and vitality at a rate of $7.3 \%$, monthly consumption of mutton and goat meat and bodily pain at a rate of $6.1 \%$, and monthly consumption of mutton and goat meat and general health perceptions at a rate of $7.1 \%$. Furthermore, a significant positive relationship was also found between monthly consumption of poultry meat and mental health at a rate of $7.4 \%$ as well as between monthly consumption of poultry meat and bodily pain at a rate of $6.3 \%$. A significant positive relationship was also found between the monthly consumption of fish meat and vitality at a rate of $9.4 \%$.

Correlation between Animal Product Consumption Amount and SF-36 Quality of Life Subscales are examined in Table 4.

Table 4. Correlation between the Amount of Animal Products Consumed and the Quality of Life Scale's Domain Scores

\begin{tabular}{|c|c|c|c|c|c|c|c|c|c|c|}
\hline $\begin{array}{l}\text { Animal } \\
\text { Products }\end{array}$ & $\begin{array}{l}\text { Consumption } \\
\text { Amount } \\
\text { Mean } \pm \mathrm{SD}\end{array}$ & $\begin{array}{c}\text { Test } \\
\text { Statistics }\end{array}$ & $\begin{array}{l}\text { Physical } \\
\text { Functioning }\end{array}$ & $\begin{array}{c}\text { Physical } \\
\text { Role } \\
\text { Limitations }\end{array}$ & $\begin{array}{c}\text { Emotional } \\
\text { Role } \\
\text { Limitations }\end{array}$ & Vitality & $\begin{array}{l}\text { Mental } \\
\text { Health }\end{array}$ & $\begin{array}{c}\text { Social } \\
\text { Functioning }\end{array}$ & $\begin{array}{l}\text { Bodily } \\
\text { Pain }\end{array}$ & $\begin{array}{c}\text { General } \\
\text { Health } \\
\text { Perceptions }\end{array}$ \\
\hline \multirow[t]{2}{*}{ Beef } & \multirow{2}{*}{$\begin{array}{l}1253.12 \pm 232 \\
96.64\end{array}$} & $\mathrm{r} / r_{G}$ & -0.007 & 0.029 & 0.037 & 0.017 & $\begin{array}{c}- \\
0.002\end{array}$ & 0.019 & 0.026 & -0.020 \\
\hline & & $\mathrm{p}$ & 0.803 & 0.313 & 0.201 & 0.557 & 0.944 & 0.507 & 0.363 & 0.495 \\
\hline \multirow{2}{*}{$\begin{array}{l}\text { Mutton- } \\
\text { Goat } \\
\text { Meat }\end{array}$} & \multirow{2}{*}{$\begin{array}{l}258.93 \\
\pm 765.24\end{array}$} & $\mathrm{r} / r_{G}$ & 0.012 & 0.037 & $0.081 * *$ & $0.073 *$ & 0.016 & -0.009 & $\begin{array}{c}0.061 \\
*\end{array}$ & $0.071 *$ \\
\hline & & $\mathrm{p}$ & 0.684 & 0.202 & 0.006 & 0.012 & 0.589 & 0.760 & 0.037 & 0.015 \\
\hline \multirow{2}{*}{$\begin{array}{l}\text { Poultry } \\
\text { Meat }\end{array}$} & \multirow{2}{*}{$\begin{array}{l}1168.38 \\
\pm 3189.66\end{array}$} & $\mathrm{r} / r_{G}$ & 0.041 & 0.022 & 0.039 & 0.038 & $\begin{array}{c}0.074 \\
*\end{array}$ & -0.005 & $\begin{array}{c}0.063 \\
*\end{array}$ & 0.045 \\
\hline & & $\mathrm{p}$ & 0.165 & 0.457 & 0.188 & 0.191 & 0.012 & 0.855 & 0.031 & 0.125 \\
\hline \multirow{2}{*}{$\begin{array}{l}\text { Fish } \\
\text { Meat }\end{array}$} & \multirow{2}{*}{$\begin{array}{l}270.29 \\
\pm 703.29\end{array}$} & $\mathrm{r} / Y_{G}$ & 0.045 & 0.023 & 0.041 & $\begin{array}{c}0.094 * \\
*\end{array}$ & $\begin{array}{c}0.063 \\
*\end{array}$ & -0.019 & 0.045 & $0.067 *$ \\
\hline & & $\mathrm{p}$ & 0.124 & 0.438 & 0.163 & 0.001 & 0.032 & 0.523 & 0.123 & 0.023 \\
\hline \multirow[t]{2}{*}{ Milk } & \multirow[t]{2}{*}{$5.12 \pm 19.67$} & $\mathrm{r} / r_{G}$ & -0.017 & 0.010 & 0.019 & 0.017 & $\begin{array}{c}- \\
0.003\end{array}$ & 0.003 & $\begin{array}{c}- \\
0.014\end{array}$ & 0.014 \\
\hline & & $\mathrm{p}$ & 0.558 & 0.728 & 0.515 & 0.575 & 0.933 & 0.918 & 0.633 & 0.629 \\
\hline \multirow[t]{2}{*}{ Cheese } & \multirow{2}{*}{$\begin{array}{l}739.84 \\
\pm 1169.68\end{array}$} & $\mathrm{r} / r_{G}$ & 0.056 & -0.029 & 0.021 & -0.004 & $\begin{array}{c}- \\
0.016\end{array}$ & 0.011 & 0.002 & 0.043 \\
\hline & & $\mathrm{p}$ & 0.053 & 0.325 & 0.465 & 0.896 & 0.595 & 0.699 & 0.943 & 0.145 \\
\hline \multirow{2}{*}{ Yoghurt } & \multirow{2}{*}{$\begin{array}{l}1512.73 \\
\pm 5180.02\end{array}$} & $\mathrm{r} / r_{G}$ & 0.036 & 0.012 & 0.015 & 0.032 & 0.025 & 0.038 & $\begin{array}{c}- \\
0.037\end{array}$ & 0.029 \\
\hline & & $\mathrm{p}$ & 0.213 & 0.691 & 0.604 & 0.274 & 0.398 & 0.194 & 0.200 & 0.314 \\
\hline \multirow{2}{*}{ Butter } & \multirow{2}{*}{$\begin{array}{l}460.76 \\
\pm 4214.27\end{array}$} & $\mathrm{r} / r_{G}$ & -0.010 & 0.027 & 0.043 & 0.028 & $\begin{array}{c}- \\
0.005\end{array}$ & 0.026 & 0.028 & -0.037 \\
\hline & & $\mathrm{p}$ & 0.738 & 0.353 & 0.142 & 0.343 & 0.866 & 0.366 & 0.339 & 0.203 \\
\hline Egg & $23.42 \pm 48.78$ & $\mathrm{r} / \mathrm{Y}_{\mathrm{g}}$ & -0.011 & -0.049 & -0.031 & 0.036 & 0.005 & -0.009 & 0.011 & 0.011 \\
\hline
\end{tabular}

Monthly consumption of fish meat and mental health also reported a significant positive relationship, at a rate of $6.3 \%$. The present study established a significant positive correlation between monthly consumption of fish meat and general health perceptions at a rate of $6.7 \%$. No significant relationship was perceived between monthly consumption of beef/veal, milk, cheese, yogurt, butter, and eggs and the domains of the quality of life scale. The monthly average consumption amounts of beef/veal, mutton/goat meat, poultry meat, and fish meat were $1,253 \mathrm{~g}$, $258 \mathrm{~g}, 1,168 \mathrm{~g}$, and $270 \mathrm{~g}$, respectively. The monthly average consumption amounts of milk, cheese, yogurt, and butter were $5.121,739 \mathrm{~g}$,
$1,512 \mathrm{~g}$, and $460 \mathrm{~g}$, respectively. The monthly average consumption amount of eggs was approximately 23 .

\section{DISCUSSION}

The objective of the present study was to evaluate the quality of life and protein-based nutrition among veterinary students in Turkey, considering the results that were in accordance with our primary purpose. Remarkable variation based on the year of study was noted in the average scores of the veterinary students in the domains of the SF-36 quality of life scale. The scores of the first-year students in each domain 
were higher than the overall average of all students and the average of other year levels. For the second- and third-year students, the quality of life scores were lower than the average value.

The intense educational activities coupled with an increase in the number and hours of courses and initiation of and vocational courses in these years (2nd and 3rd) may justify the reduced quality of life scores. Some relevant studies opined that veterinary students get the feeling that they will never be able to finish the school due to the all-day-long classes and challenging exams and give off other aspects of life to overcome this feeling (Labbafinejad et al., 2016; Kogan et al., 2005). The quality of life scores reverted to the average level for the fourth- and fifth-year students. An increase in the scores at these year levels must be attributed to the reduced number of courses in the fifth-year fact and initiation of their internship training program

As they approach the end of their university life, they feel more relaxed mentally and can perceive their potential to become a veterinarian. A similar study in Brazil reported, in line with the findings of the present study, that the quality of life of medical students dropped to the minimum level in their third year, which could arise due to the burden of academic knowledge and that it returned The objective of the present study was to evaluate the quality of life and protein-based nutrition among veterinary students in Turkey, considering the results that were in accordance with our primary purpose. Back to normal levels in the fourth and fifth years [29, 30]. Another study conducted on university students in Serbia, the lowest quality of life was obtained among the group studying health sciences (Pekmezovic et al., 2011).

While in a study conducted on veterinary students in Iran the average scores in the domains of the quality of life scale (81.70 in physical functioning, 53.61 in physical role limitations, and 47.78 in emotional role limitations) were found to be lower than the scores of the veterinary students in Turkey. However, their scores in energy/pep/vitality (59.27), mental health (64.64), social functioning (64.68), bodily pain (73.58), and general health perceptions (63.62) were higher than that obtained for the veterinary students in Turkey.
The veterinary education in Iran is six years, and the number of courses per semester is less than that in Turkey. This may be the underlying cause of the difference in the scores of the students in these two regions.

The study in Iran also estimated the quality of life scores of medical students, which were higher than those of the veterinary students in all domains, excluding social functioning (Labbafinejad et al., 2016). The reduced quality of life scores of veterinary students can be explained by the fact that they encounter medical cases of various animal groups that they have never seen before, face injury risks when dealing with animals, and, by extension, feel a dearth of self-confidence during their education (Labbafinejad et al., 2016). A study in Serbia elucidated a higher value of life scores for university students in all domains as compared to the scores of the veterinary students in Turkey (Pekmezovic et al., 2011).It is asserted that environmental factors are the major contributor to reduced general health and mental health scores in Turkey than those in other countries (Arslan et al., 2009).

The quality of life scores computed according to the gender observed higher scores in the case of male students. The scores in the domains of physical functioning, energy/pep/vitality, bodily pain, and general health perceptions were high, as illustrated in Table 2. A similar study conducted on veterinary students reported higher and statistically significant quality of life scores for male students than female students (Labbafinejad et al., 2016). A study involving students from a single university also showed a higher value of the quality of life scores in all domains in the case of male students as compared to those of female students (Pekmezovic et al., 2011).

The quality of life scores of the students residing with their family or relatives were higher than those of the students living with their friends in student houses and dormitories and the average scores. Remarkably, the physical role limitation and emotional role limitation scores of the students living in student houses were lower than both the average scores and other groups. The statistically significant difference was observed for the group living in student houses only in the domain of physical role limitation. However, 
statistical significance was absent between the scores of the other domains of SF-36. The results from another study were in-line with the observations from the present study. This study also demonstrated that the students residing with their family had a higher quality of life scores than those of students dwelling alone or in dormitories (Pekmezovic et al., 2011). However, no significant correlation was obtained between the accommodation status and quality of life score in a study conducted in Brazil (Paro et al., 2010).

Table 3 exemplified important findings regarding quality of life scale scores by individual monthly income, expenditure on foods, and expenditure on animal products. One of them was the quality of life scores by income range. Escalation of quality of life score was witnessed with the increase in the monthly income of the veterinary students. Increased revenue was associated with improved scores in physical role limitation, emotional role limitation, energy/pep/vitality, mental health, bodily pain, and general health perception. This statistically significant improvement must be arising out of the rising level of welfare. The difference in the two extreme groups of income, namely, below 300 TRY and above 1,500 TRY was statistically significant, which thereby confirmed the hypothesis.

This observation was in accordance with the study conducted in Serbia that documented the SF-36 scores of university students increased significantly (based on statistical computation) with the increase in their families' monthly income (Pekmezovic et al., 2011). Moreover, economic and social security was also associated with increased quality of life. Families of a large majority of the veterinary students were inhabitants of rural areas. This is predicted to be another reason for slightly lower quality of life scores than those of students in other faculties because it is reported that people living in rural areas are in a more inconvenient position as compared to those residing in urban areas, as far as income level is concerned (McNaughton et al., 2012).

Unlike the increase in monthly income, the increase in individual monthly expenditure on food did not result in improvement in each domain. As the veterinary students' individual monthly expenditure on food increased, their scores in energy/pep/vitality, mental health, social functioning, bodily pain, and general health perceptions increased as well. The scores in the abovementioned domains increased because a budget set aside for foods ensured a higher level of consumption of foods with better qualities. Relevant studies published that nutrition is one of the predominant factors affecting the quality of life (McNaughton et al., 2012).

Regarding individual monthly expenditure on animal products, the quality of life score increased up to a certain limit with the increase in the expenditure; after that, it stopped increasing at a certain point even if the expenditure increased. This must be owing to the limited capacity of the human stomach to consume a certain amount of animal products. This was also evident from the domain scores of the scales. Statistical differences of the scores in physical functioning, energy/pep/vitality, mental health, bodily pain, and general health perception were restricted to the groups spending below 50 TRY, 150-199 TRY, and 200-299 TRY on animal products.

Statistical difference failed to appear in the group spending 300 TRY and above on animal products. One of the major findings that need to be addressed is enhanced scores in mental health, and general health perception is associated with the rise in the budget set aside for, and thus the consumption of animal products. Based on this finding, we can conclude that sufficient production and consumption of animal products is necessary for the physical and mental health of individuals in a society. A primary criterion for this sufficiency is that the livestock sector should reach the desired level.

\section{CONCLUSION}

By determining the status and mapping of the quality of life, the production and consumption balance was examined based on animal protein. Estimation of the correlation between the domain scores and the animal products consumed, an insignificant relationship was found between consumption of beef/veal and the domains of the quality of life scale. The explanation behind such observation must be due to the fact that more than $80 \%$ of the red meat produced in Turkey is 
beef/veal and is somehow consumed by any segment of the society. However, a positive relationship was perceived between the amount of consumption of mutton and goat meat and the scores in emotional role limitation, energy/pep/vitality, bodily pain, and general health perception. In other words, as the consumption of mutton and goat meat increases, the scores in the abovementioned domains increase as well, implying a better quality of life of the participants. This derivation was also applicable to the relationship between the consumption of poultry meat and the domains of mental health and bodily pain. The positive relationship between consumption of fish and the domains of energy/pep/vitality, mental health, and general health perception indicated the major linkage between the society's potential to be energetic and possess good mental health and general health perceptions and consumption of a sufficient amount of meat and meat products in a balanced diet. The abovementioned points orchestrate the fact that quality of life scores of the students can be improved by enhancing their consumption of mutton, goat, and fish. The reason why no significant relationship could be found between consumption of milk, dairy products, and eggs, and the scores in the domains of the quality of life scale may be because of the easy accessibility of such products in Turkey, and they are also more affordable than meat and meat products. The weaknesses of the study are that it is cross-sectional and is based on statements of the respondents. Strengths of the present study include that it was conducted across all veterinary faculties in Turkey, its results reflected country-wide conditions, it enabled evaluation of the quality of life by income range, it addressed the relationship between consumption of animal products and quality of life in terms of both budget and level of consumption, and it was one of the few studies that contained such aspects. With the growing population in Turkey, the demand for food and animal products is increasingly rising. Measures should be procured to encourage production and consumption of mutton/goat meat, chicken, and fish to be able to raise the level of welfare in proportion to the growing population. In this context, it is postulated that the mental health and general health perceptions of both the veterinary students and the general public will be better if the consumption of such products increases. Moreover, remodeling of the curriculum of veterinary faculties by incorporating information regarding the relationship between consumption of animal products and quality of life into with an emphasis on the importance of the sub-sectors of the livestock industry will give a different vision to students.

\section{AUTHORS' CONTRIBUTIONS}

MAT Performing statistical analysis, determining the main topic and contributor in writing. $\mathrm{MBC}$ as a major contributor in writing the manuscript. ACA in collection of Data and Arrangement of Official Documents. BM Collection of Data. MSA Collection of Data. MP Organization. All authors read and approved the final manuscript. The data related to the article is ready to be sent to the desired place quickly when necessary.

\section{REFERENCES}

ARGON, T.; KÖSTERELIOĞLU, M. Üniversite öğrencilerinin üniversite yaşam kalitesi ve fakülte kültürüne ilişkin algıları. Elektronik Sosyal Bilimler Dergisi, v.8, p.43-61, 2009.

ARSLAN, G.; AYRANCI, U.; UNSAL, A.; ARSLANTAS, D. Prevalence of depression, its correlates among students, and its effect on healthrelated quality of life in a Turkish university. Ups. J. Med. Sci., v.114, p.170-177, 2009.

BOTEV, Z.; RIDDER, A. Variance reduction. Wiley StatsRef: statistics reference. doi:10.1002/9781118445112.stat07975.

BOYLU, A.A.; PAÇACIOĞLU, B. Yaşam kalitesi vegöstergeleri. Akademik Araştırmalar Çalışmalar Dergisi, v.8, p.137-150, 2016.

BRAZIER, J.; ROBERTS, J.; DEVERILL, M. The estimation of a preference-based measure of health from the SF-36. J. Health Econom., v.21, p.271-292, 2002.

CEVGER, Y.; ARAL, Y.; DEMIR, P.; SARIÖZKAN, $\mathrm{S}$. The situation of animal products consumption and consumer preferences among intern students at the Ank. Univ. Fac. Vet. Med., v.55, p.189-194, 2008.

ERDOĞAN, N.; ÇIÇEK, H. Hayvansalgıdaların tüketim yapısı ve tüketici tercihlerinin belirlenmesi üzerine bir araştırma: üniversite personeli örneği. Kocatepe Vet. J., v.8, p.25-31, 2015. 
ESFAHANI, M.S.; DOUGHERTY, E.R. Effect of separate sampling on classification accuracy. Bioinformatics, 2014; v.30, p.242-250 2014.

FRANKS, P.; LUBETKIN, E.I.; GOLD, M.R.; TANCREDI, D.J.; JIA, H. Mapping the SF-12 to the EuroQol EQ-5D Index in a national US sample. Med. Dec. Making, v.24, p.247-254, 2004.

GELBERG, S.; GELBERG, H. Stress management interventions for veterinary students. J. Vet. Med. Educ., v.32, p.173-181, 2005.

GOLDIN, S.B.; WAHI, M.M.; FAROOQ, O.S.; BORGMAN, H.A. et al. Student quality of life declines during third year surgical clerkship. J. Surg. Res., v.143, p.151-157, 2007.

IBM SPSS Statistics for Windows, Version 25.0. Armonk, NY: IBM Corp. 2017.

JENKINSON, C.; LAYTE, R.; JENKINSON, D. et al. A shorter form health survey: can the SF-12 replicate results from the SF-36 in longitudinal studies? $J$. Public Health, v.19, p.179-186, 1997.

KOÇYIĞIT, H.; AYDEMIR, Ö.; ÖLMEZ, N.; MEMIŞ, A. Kısa Form-36 (KF-36) 'nın Türkçe versiyonunun güvenilirliği vegeçerliliği. İlaç Tedavi Dergisi, v.12, p.102-106, 1999.

KOGAN, L.R.; MCCONNELL, S.L; SCHOENFELD-TACHER, R. Veterinary students and non-academic stressors. J. Vet. Med. Educ., v.32, p.193-200, 2005.

LABBAFINEJAD, Y.; DANESH, H.; IMANIZADE, $Z$. Comparison of the perceived quality of life between medical and veterinary students in Tehran. J. Vet. Med. Educ., v.43, p.41-46, 2016.

MCNAUGHTON, S.A.; CRAWFORD, D.; BALL, K.; SALMON, J. Understanding determinants of nutrition, physical activity and quality of life among older adults: the Wellbeing, Eating and Exercise for a Long Life (WELL) study. Health Q. Life Outcomes, v.10, p.109, 2012.

PARO, H.B.; MORALES, N.M.; SILVA, C.H. et al. Health-related quality of life of medical students. Med. Educ., v.44, p.227-235, 2010.

PATRICK, D.L.; ERICHSON, P. Health status and health policy: quality of life in health care evaluation and resource allocation. New York: Exford University Pers, 1993. p.117-119.
PEKMEZOVIC, T.; POPOVIC, A.; TEPAVCEVIC, D.K.; GAZIBARA, T.; PAUNIC, M. Factors associated with health-related quality of life among Belgrade University students. Q. Life Res., v.20, p.391-397, 2011.

SARIÖZKAN, S.; CEVGER, Y.; DEMIR, P.; ARAL, Y. Erciyes Üniversitesi Veteriner Fakültesi öğrencilerinin hayvansal ürün tüketim yapısı ve alışkanlıkları. Sağlık Bilimleri Dergisi, v.16, p.171179, 2007.

ŞENTÜRK, B. Ondokuz Mayıs Üniversitesi Veteriner Fakültesi öğrencilerinin hayvansal ürün tüketim harcamalarının analizi. Vet. Hekimler Derneği Dergisi, v.82, p.71-78, 2011.

MEAT consumption (indicator). The Organisation for Economic Co-operation and Development OECD. 2018. Available in: https://data.oecd.org/agroutput/meatconsumption.htm. Accessed in: 15 Dec. 2018

THE WORLD Health Organization Quality of Life assessment (WHOQOL): position paper from the World Health Organization. Soc. Sci. Med., v.41, p.1403-1409, 1995.

TOZUN, M.; UNSAL, A.; AYRANCI, U.; ARSLAN, G. Prevalence of disordered eating and its impact on quality of life among a group of college students in a province of west Turkey. Salud Publica Mex., v.52, p.190-198, 2010.

UNSAL, A.; AYRANCI, U.; TOZUN, M.; ARSLAN, G.; CALIK, E. Prevalence of dysmenorrhea and its effect on quality of life among a group of female university students. Ups. J. Med. Sci., v.115, p.138145,2010 .

WALTERS, S.J.; BRAZIER, J.E. What is the relationship between the minimally important difference and health state utility values? The case of the SF-6D. Health Q. Life Outcomes, v.1, p.4, 2003.

WARE, J.E.; SHERBOURNE, C.D. The MOS 36 item short form health survey (SF-36). Conceptual framework and item selections. Med. Care, 30, p.473483, 1992.

YÜCEL, A. Et ve su ürünleri teknolojisi. Uludağ Üniv. Ziraat Fak. Ders notları 4. Bask1. Yayın, n.47, 2016. 